\title{
KEANEKARAGAMAN DAN REKAMAN BARU JENIS LUMUT DI PULAU SUMATRA
}

\author{
Kasiani $^{1^{*}}$, Budi Afriyansyah ${ }^{1}$, Lina Juairiah $^{2}$ \& Florentina Indah Windadri ${ }^{3}$ \\ ${ }^{1}$ Program Studi Biologi FPPB- Universitas Bangka Belitung \\ ${ }^{2}$ Dinas Lingkungan Hidup, Sungailiat, Kabupaten Bangka \\ ${ }^{3}$ Bidang Botani, Pusat Penelitian Biologi, Lembaga Ilmu Pengetahuan Indonesia, Cibinong 16911 \\ "kasiani.ubb@gmail.com; ${ }^{1}$ budikysh@gmail.com
}

Kasiani, Budi Afriyansyah, Lina Juairiah \& Florentina Indah Windadri. 2019. Bryophytes Diversity and New Records of Sumatra. Floribunda 6(3): 85-92. - Inventory of bryophyte in conservation and tourism areas at Peramun hill, Air Selumar Village, Sijuk District, Belitung has been conducted to determine the diversity of bryophyte. Exploration methods were used in this study site with 15 specified location points. The results recorded 28 species of bryophyte consisting of 20 species of mosses, 6 species of leafy liverworts and 2 species of liverworts. Calymperaceae and Lejeuneaceae are common bryophyte in the study site. As many as 7 species (4 species of liverworts and 3 species of mosses) are reported as new records for the Sumatra Island.

Keywords: Mosses, Peramun Hill Areas, new record, Sumatra Island.

Kasiani, Budi Afriyansyah, Lina Juairiah \& Florentina Indah Windadri. 2019. Keanekaragaman dan Rekaman Baru Jenis Lumut di Pulau Sumatra. Floribunda 6(3): 85-92. - Inventarisasi tumbuhan lumut di kawasan konservasi dan destinasi wisata Bukit Peramun, Desa Air Selumar, Kecamatan Sijuk, Belitung telah dilakukan untuk mengetahui keanekaragaman jenisnya. Metode jelajah atau eksplorasi digunakan dalam penelitian ini, dengan area jelajah pada 15 titik lokasi yang banyak ditemukan lumut. Hasil penelitian mencatat 28 jenis lumut yang terdiri dari 20 jenis lumut sejati $(5$ suku) dan 8 jenis lumut hati $(5 \mathrm{suku})$. Calymperaceae (lumut sejati) dan Lejeuneaceae. (lumut hati berdaun) merupakan lumut yang paling banyak ditemukan dilokasi penelitian yaitu sebanyak 7 jenis (4 jenis lumut hati dan 3 jenis lumut sejati) dilaporkan sebagai rekaman baru bagi Pulau Sumatera.

Kata kunci: Lumut, Kawasan Bukit Peramun, rekaman baru, Pulau Sumatra.

Lumut merupakan tumbuhan tingkat rendah yang tidak memiliki jaringan pembuluh (Siregar 2010). Tumbuhan ini termasuk dalam kelompok yang bisa tumbuh di berbagai substrat seperti kayu lapuk, serasah, batang pohon, batu dan daun. Lumut juga merupakan kelompok terbesar kedua setelah tumbuhan tingkat tinggi (Windadri 2010).

Habitat pertumbuhan lumut banyak dijumpai di dataran rendah dan dataran tinggi misalnya di kawasan hujan tropis, pegunungan dan bukit. Pertumbuhan lumut sangat dipengaruhi oleh faktor lingkungan khususnya lingkungan mikro seperti kelembaban, suhu, intensitas cahaya dan ketinggian tempat. Kelembaban udara yang diperlukan untuk pertumbuhannya berkisar antara 70-90\% (Mulyani et al. 2015; Wati et al. 2016).

Keanekaragaman jenis lumut di Indonesia sekitar 1500 jenis (Bawaihaty et al. 2014). Penelitian keanekaragaman jenis lumut di Indonesia pernah dilakukan oleh beberapa peneliti antara lain Yamagutchi et al. 2005; Windadri 2007, 2009; Haerida et al. 2010; Bachri 2012; Putrika 2012; Satiyem 2012; Windadri \& Susan (2013); Bawaihaty et al. 2014; Febrianti 2015;
Mulyani et al. 2015; Wati et al. 2016. Penelitian mengenai lumut di Pulau Sumatera telah dilakukan oleh: Dixon 1932; Ho et al. 2006; Ellizarti 2009; Windadri 2010; Siregar 2010; Pradana 2013; Siregar 2015; Iswanto dkk 2016; Windadri \& Rosalina 2017; Rosyanti et al. 2018; Nadhifah et al. 2018; Fajriah 2018; Hardianty 2018.

Provinsi Bangka Belitung yang terletak di sisi timur Pulau Sumatera merupakan deretan pulau-pulau kecil yang mempunyai kondisi geografis datar hingga berbukit. Beberapa hutan konservasi juga ditemukan di wilayah ini. Penelitian keanekaragaman hayati di Provinsi ini khususnya lumut telah dilakukan di beberapa tempat oleh Rosyanti (2017) di Bangka Flora Society, Rangkuti (2017) di Hutan Konservasi Pelawan, dan Riani (2017) di Bukit Maras. Sedangkan di Kawasan Bukit Peramun belum pernah dilakukan pendataanya. Pendataan keanekaragaman hayati di Kawasan Bukit Peramun pernah dilakukan terutama keanekaragaman tumbuhan obat dan anggrek, sedangkan pendataan keanekaragaman lumutnya belum pernah dilaporkan. Oleh karena itu perlu dilakukan 
inventarisasi, untuk melengkapi data keanekaragaman hayati di Kawasan Bukit Peramun, Kabupaten Belitung.

\section{BAHAN DAN METODE}

Penelitian ini dilaksanakan pada bulan Agustus-Oktober 2018. Penelitian dilakukan dengan dua tahap yaitu tahap pertama pengambilan sampel di Kawasan Bukit Peramun dengan ke- tinggian Bukit 129 mdpl. dengan luas $115 \mathrm{Ha}$ (Komunitas Arsel 2018). Lokasi penelitian terletak pada koordinat $2^{\circ} 37^{\prime} 1.73^{\prime \prime}$ LS dan 10744'7.07" BT. Tahap yang kedua yaitu identifikasi tumbuhan lumut yang dilakukan di Herbarium Bangka Belitungense, Universitas Bangka Belitung. Identifikasi juga dilakukan di Laboratorium Kriptogran Bidang Botani Lembaga Ilmu Pengetahuan Indonesia (LIPI) Cibinong. Lokasi penelitian terdapat pada Gambar 1.

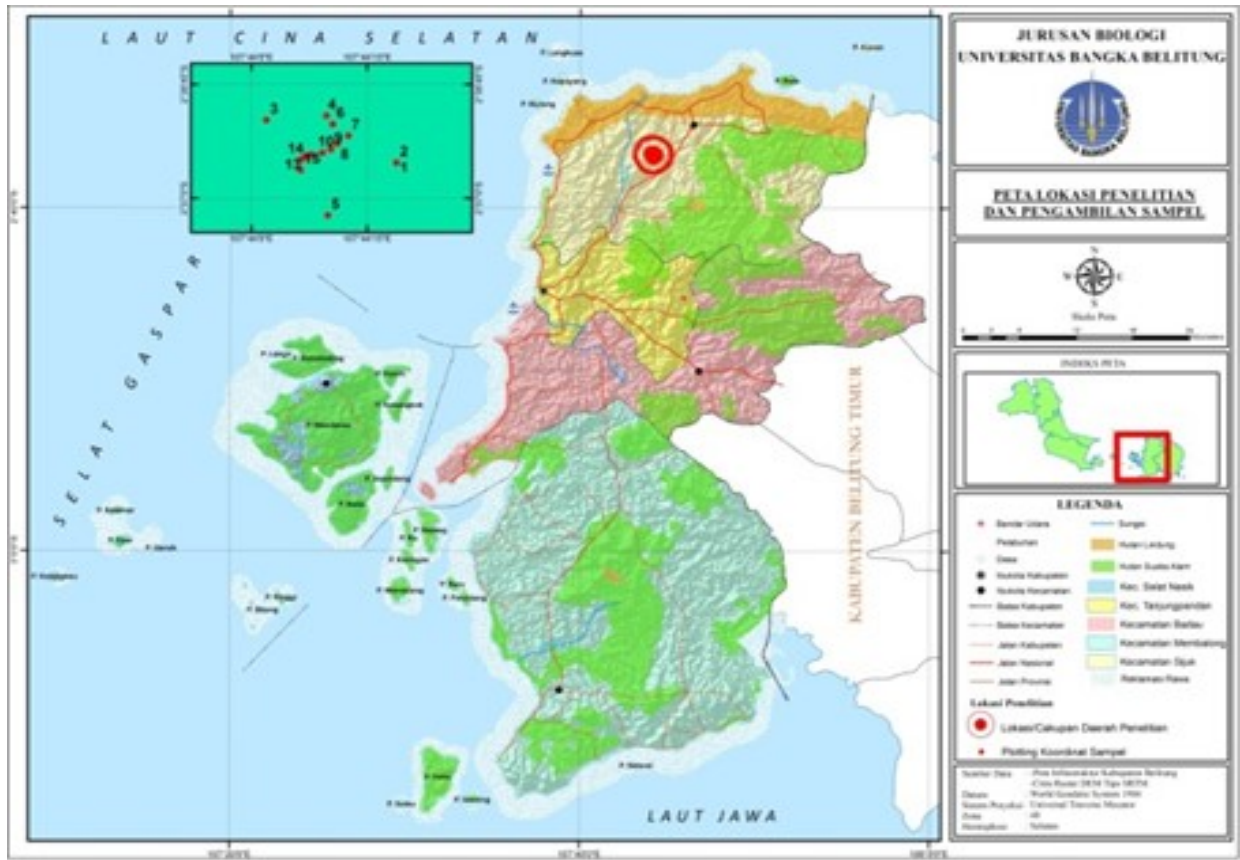

Gambar 1. Titik lokasi penelitian di Kawasan Bukit Peramun.

Metode jelajah (Rugayah dkk. 2004) telah digunakan dalam penelitian ini. Semua jenis tumbuhan lumut yang sudah ditemukan pada lokasi penelitian akan dikoleksi dan dicatat data sekundernya meliputi: substrat (tanah, batu, pohon, kayu mati, kayu lapuk dan daun), kondisi lingkungan (secara kualitatif) dan dibuat dokumentasinya. Sampel lumut dimasukkan dalam amplop, jika tidak segera diidentifikasi sampel lumut dikering anginkan. Lumut yang sudah dikeringkan dimasukkan ke dalam amplop terpisah, diberi label berisi nomor dan nama kolektor, tanggal dan lokasi koleksi, ketinggian tempat.

Identifikasi tumbuhan lumut dilakukan di Laboratorium Kriptogram Bidang Botani, Pusat Penelitian Biologi-LIPI, Cibinong, Bogor, Jawa Barat dengan menggunakan mikroskop binokuler dan stereo. Beberapa buku acuan yang digunakan untuk identifikasi yaitu mosses of the Philippines (Bartram 1939), Moss Flora of The National Bota- nic Garden, Philippines (Rosario 1979), A Handbook of Malesian Mosses vol 1 (Eddy 1988), A Handbook of Malesian Mosses vol 2 (Eddy 1990), A Handbook of Malesian Mosses vol 3 (Eddy 1996), Guide to the Liverworts and Hornworts of Java (Gradstein 2011).

Penentuan status taksonomi dari jenis-jenis lumut yang ditemukan dilakukan penelusuran daerah persebarannya baik secara manual maupun digital melalui buku-buku seperti yang digunakan dalam identifikasi dan juga hasil-hasil penelitian

\section{HASIL DAN PEMBAHASAN}

Inventarisasi lumut di lokasi penelitian telah diperoleh sebanyak 39 nomor dan telah teridentifikasi menjadi 28 jenis yang dikelompokkan dalam lumut sejati (20 jenis terdiri dari 4 ordo dan 5 famili), lumut hati berdaun ( 6 jenis) dan lumut hati berthalus ( 2 jenis) terdiri dari 3 ordo dan 5 famili. Lumut sejati merupakan kelompok lumut dengan 
perawakan yang dapat dibedakan antara rhizoid, batang, daun, dan sporofit. Lumut sejati memiliki alat kelamin yang terkumpul di bagian ujung cabang dan dikelilingi oleh daun-daun yang terletak paling atas (Tjitrosoepomo 2011). Lumut hati berdaun merupakan kelompok lumut peralihan antara lumut hati dengan lumut sejati. Bentuk perawakannya menyerupai lumut sejati tetapi susunan sel-sel pada daunnya menyerupai sel-sel pada lumut hati demikian juga dengan tipe sporofitnya. Pada kelompok lumut hati mempunyai perawakan berupa lembaran yang sering disebut talus.

Family Calymperaceae sering ditemukan di lokasi penelitian yaitu sebanyak 7 jenis yaitu $\mathrm{Ca}$ lymperes afzelii Sw., Calymperes palisotii Schwagr., Calymperes graeffeanum Mull. Hal., Calymperes porrectum Mitt, Leucophanes octoblepharoides (Schwagr.) Linb., Mitthyridium repens (Harv). Robinson dan Octoblepharum albidum Hedw. Anggota suku Calymperaceae juga dilaporkan mendominasi di tempat-tempat lain seperti laporan Rangkuti (2017) yang meneliti di Hutan Pelawan, Bangka Tengah. Penelitian mengenai lumut juga dilaporkan oleh Riani (2017) di Kawasan Hutan Air Terjun Bukit Maras Desa Dalil, Bangka. Di pulau lain Windadri \& Susan (2013) juga melaporkan hal yang sama dari Kepulauan Raja Ampat, Papua Barat.

Suku Calymperaceae merupakan kelompok lumut sejati yang sering dilaporkan dominan pada beberapa lokasi karena lumut kelompok ini mempunyai toleransi habitat yang cukup luas, sehingga keberadaanya mudah ditemukan di berbagai tipe habitat. Selain itu Calymperaceae mempunyai dua macam alat perkembangbiakan yaitu alat perkembangbiakan generatif berupa spora dan alat perkembangbiakan vegetatif berupa kuncup (gemmae) yang terdapat di ujung-ujung daunnya. Apabila kuncup-kuncup ini terlepas dari ujung daunnya dan jatuh di substrat yang cocok serta didukung oleh lingkungan yang sesuai dapat tumbuh dan berkembang menjadi tumbuhan lumut baru (Win-dadri \& Susan 2013). Adanya dua macam alat perkembangbiakan maka persebarannya lebih luas dibandingkan dengan jenis lumut lainnya, sehingga keberadaannya di alam sering ditemukan. Sedangkan untuk kelompok lumut hati suku Lejeuneaceae juga merupakan suku yang sering ditemukan di lokasi penelitian, terdiri dari 4 jenis yaitu Cheilolejeunea conchifolia (A. Evans) W. Ye \& R.L. Zhu, Depranolejeunea sp., Drepanolejeunea tricornua Herzog. dan Lejeunea eckloniana Lindenb.

Lejeuneaceae merupakan salah satu suku dari kelompok lumut hati berdaun yang memiliki keanekaragaman jenis paling besar. Schuster (1980) melaporkan bahwa keanekaragaman jenisnya mencapai lebih dari 1600 jenis yang tercakup dalam 68 marga dan setara dengan 20$25 \%$ dari semua lumut hati. Berdasarkan karakter taksonominya, beberapa jenis dari suku ini bagian ventral daunnya mengalami modifikasi membentuk cuping yang disebut lobule. Lobule mempunyai peranan sebagai penampung/penyimpan air, sehingga pada saat kekeringan kelompok lumut ini dapat beradaptasi dengan lingkungan dan masih mampu mempertahankan diri (Gradstein \& Pocs 1989). Oleh karena sifatnya yang demikian dan didukung oleh keanekaragaman jenisnya yang paling besar maka jenis ini mudah ditemukan di lokasi penelitian.

\section{Rekaman Baru lumut di Sumatera}

Untuk melihat lebih jauh status taksonomi dari lumut-lumut yang ditemukan di lokasi penelitian maka dilakukan penelusuran melalui berbagai pustaka baik secara digital maupun manual. Berdasarkan laporan di beberapa kawasan Sumatera: Ho et al. (2006) A Checklist of Mosses of Sumatra, Indonesia; Windadri (2010) di Taman Nasional Bukit Barisan Selatan, Provinsi Lampung; Siregar et al. (2014) di Hutan Sibayak Sumatra Utara; Rosyanti et.al (2017) di Kebun Botani, Bangka Flora Society, Bangka dan Nadhifah et al. (2018) di Kawasan Hutan Lindung Gunung Sibuatan, Sumatra Utara belum pernah melaporkan 7 jenis yang ditemukan dalam penelitian ini, sehingga bisa dikatakan sebagai rekaman baru, Sumatera.

Hasil penelusuran yang didasarkan pada daerah persebarannya dapat diketahui bahwa 7 jenis lumut tersebut dikategorikan sebagai rekaman baru bagi Pulau Sumatera. Jenis-jenis lumut tersebut terdiri dari 3 jenis termasuk dalam kelompok lumut sejati yaitu Fissidens virens Thwaites \& Mitt., Trichosteleum stigmosum Mitt. dan Brotherella nictans (Mitt.) Broth.; 4 jenis termasuk ke dalam kelompok lumut hati Cheilolejeunea conchifolia (A. Evans) W. Ye \& R.L. Zhu, Chiloscypus profundus (Nees) J.J. Engel \& R.M. Schust, Drepanolejeunea tricornua Herzog, dan Lejeunea eckloniana Lindenb. Lumut rekaman baru Sumatera terdapat pada Gambar 2. 

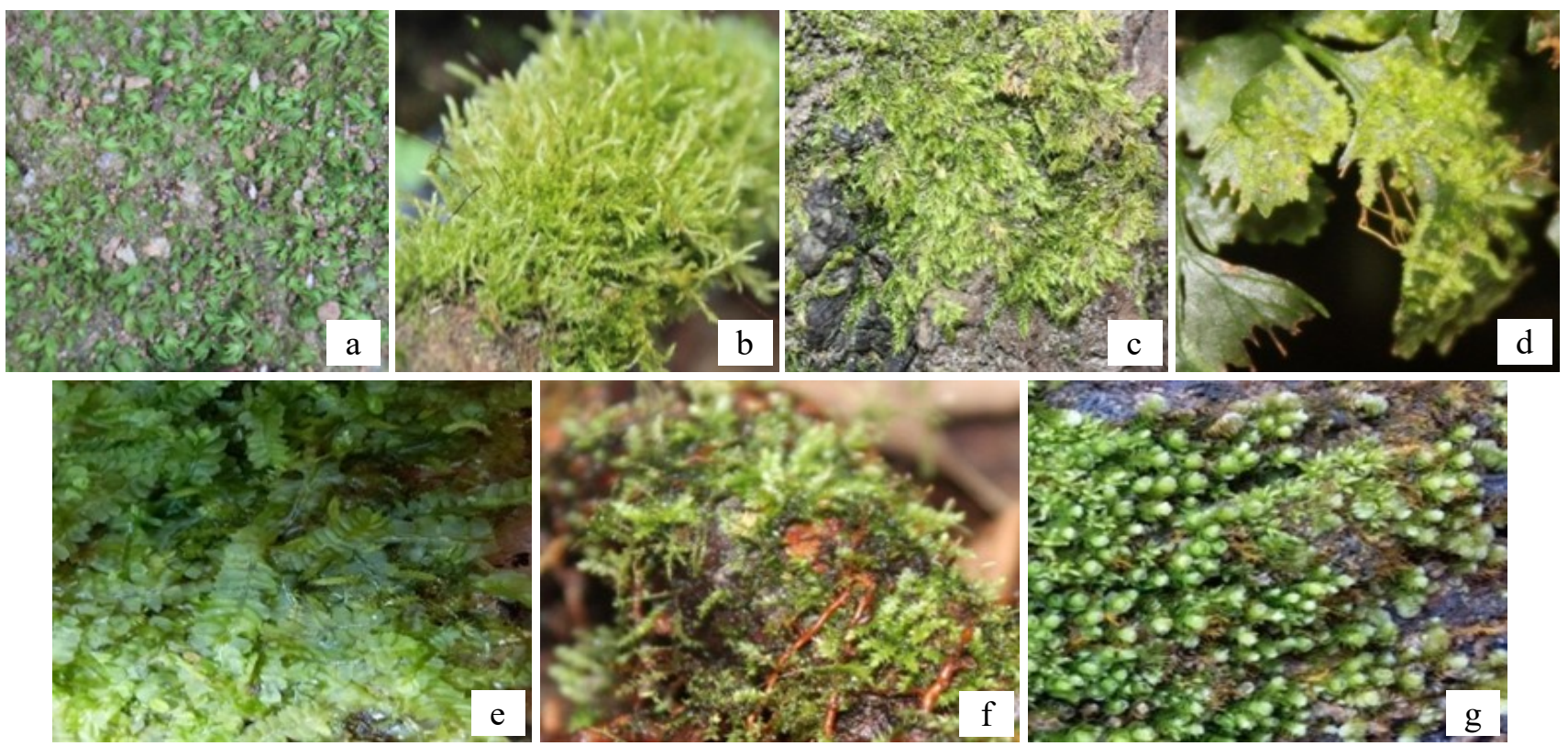

Gambar 2. Beberapa jenis lumut rekaman baru di Sumatera (a). Fissidens virens Thwait. \& Mitt. (b). Brotherella nictans (Mitt.) Broth. (c). Trichosteleum stigmosum Mitt (d). Cheilolejeunea conchifolia (A. Evans) W. Ye \& R.L. Zhu (e). Chiloscypus profundus (Nees) J.J. Engel \& R.M. Schust (f). Drepanolejeunea tricornua Herzog (g). Lejeunea eckloniana Lindenb.

\section{Briophyta di Bukit Peramun}

Penulisan keanekaragaman jenis jenis lumut dari lokasi penelitian mengikuti sistem penamaan Söderström et al. (2010). Ka merupakan inisial nama kolektor dari “ Kasiani”. Untuk lumut yang berstatus sebagai rekaman baru bagi Pulau Sumatera diberi tanda (*). Semua spesimen lumut disimpan di Herbarium Bangka Belitungense, Universitas Bangka Belitung, Provinsi Bangka Belitung.

\section{Lumut sejati}

Calymperaceae

Calymperes afzelii Sw., tumbuh di akar pohon Puspa, semi ternaungi, 70 mdpl. Ka.10

Distribusi: tersebar di Seluruh Malesia (Eddy 1990).

Calymperes graeffeanum Müll. Hal., tumbuh di batu, semi terbuka, 50 mdpl. Ka.1

Distribusi: Malesia, Asia tropik, dan Polynesia, tersebar sepanjang wilayah lautan India dan mungkin Afrika (Eddy 1990).

Calymperes palisotii Schwägr., tumbuh di batu, ternaungi, 98 mdpl. Ka.5

Distribusi: Malesia, Jawa, Afrika dan Amerika (Fleischer 1908 \& Eddy 1988 dalam Windadri 2009).

Calymperes porrectum Mitt., tumbuh di kayu lapuk, ternaungi, 50 mdpl. Ka.6

Distribusi: Jawa, Sumatra, Kalimantan,
Sulawesi, Malaysia, Filipina, Papua Nugini, India, Sri Lanka, dan Oseania (Eddy 1990).

Leucophanes octoblepharoides (Schwägr.)

Linb., tumbuh di batu, ternaungi, 81 mdpl. Ka.14

Distribusi: Malaysia, India, Sri Lanka, Indo-

Pasifik (Eddy 1990).

Mitthyridium repens (Harv). Robinson, tumbuh di batang pohon jurong, semi ternaungi, 50 mdpl. Ka.2

Distribusi: Malesia, Filipina, Poynesia, dan Australia Utara (Eddy 1990).

Octoblepharum albidum Hedw., tumbuh di batang pohon jurong, semi ternaungi, $50 \mathrm{mdpl}$. Ka.18

Distribusi: seluruh dunia di daerah tropis (William 2007).

\section{Fissidentaceae}

Fissidens geppi M.Fleisch., tumbuh di tanah, terbuka, 55 mdpl, Ka.7

Distribusi: Jawa, Sumatra, Borneo, India, Nepal, China, Korea, dan Jepang (Pradhan \& Joshi 2006).

Fissidens hollianus Dozy \& Molk., tumbuh di kayu mati, ternaungi, 81 mdpl, Ka.11

Distribusi: Jawa, Sumatra, Borneo, Malay Peninsula, Filipina, China, Indochina, Thailand, Burma, Nepal, Myanmar, Taiwan, Jepang, Papua New Guinea, Vietnam, India, Korea (Pradhan \& Joshi 2006). 
*Fissidens virens Thwait. \& Mitt, tumbuh di tanah, ternaungi, 98 mdpl, Ka.19

Distribusi: India, Nepal, Sri Lanka, Formosa, dan Vietnam (Pradhan \& Joshi 2006).

\section{Hypnaceae}

Isopterygium albescens (Hook.) Jaeg., tumbuh di kayu mati, ternaungi, 70 mdpl Ka.15

Distribusi: Jawa, Sumatra, Borneo, Sulawesi, Malaysia, Filipina, Cina, India, Jepang, Kamboja, Laos, Myanmar, Nepal, Sikkim, Sri Lanka, Taiwan, Vietnam (anonymous 2012 dalam Windadri 2014).

Vesicularia miquelii (Sande Lac.) M. Fleisch., tumbuh di kayu mati, ternaungi, 80 mdpl. Ka.20

Distribusi: Selangor, Peninsular Malaysia (Damanhuri \& Maideen 2001), Distrik Morobe, Northeast New Guinea (Bartram 1945).

\section{Dicranaceae}

Leucobryum candidum (P. Beauv).Wils., tumbuh di kayu mati, ternaungi, 55 mdpl, Ka.22

Distribusi: Malesia, Australia, Polynesia (Eddy 1990).

Leucobryum javense (Brid.) Mitt., tumbuh di kayu mati, ternaungi, 55 mdpl, Ka.28

Distribusi: Malesia, Polynesia, Australia Utara (Eddy 1990 dalam Rosyanti 2017).

Leucobryum juniperoideum (Brid.) Müll. Hal., tumbuh di atas batu, ternaungi, $80 \mathrm{mdpl}$, Ka.21

Distribusi: Jawa, Sumatra, Kalimantan, Sulawesi, New Guinea, Filipina, Macronesia, Madagascar, Turki, Caucasus, Jepang, Korea, Taiwan, Cina, Himalaya, India, Sri Lanka, Myanmar, Thailand, Eropa (Windadri \& Susiarti 2005)

\section{Sematophyllaceae}

Acanthorrhynchium papillatum (Harv.) M.

Fleisch., tumbuh di pohon ulin, ternaungi, 85 mdpl, Ka.23

Distribusi: Indonesia, Malaysia dan Australia. (Damayanti et. al 2006).

*Brotherella nictans (Mitt.) Broth., tumbuh di kayu mati, terbuka, 50 mdpl, Ka.3

Distribusi: Malaysia, Asia Barat Daya, China, Turki, Mediterania (Alatas et al 2016).

Sematophyllum saproxylophilum (Müll. Hal.) M. Fleisch., tumbuh di daun (serasah), semi ternaungi, $89 \mathrm{mdpl}$, Ka.27

Distribusi: Sumatera (Ho et al. 2006).

Sematophyllum sp., tumbuh di batu, ternaungi, 89 mdpl, Ka.4
*Trichosteleum stigmosum Mitt., tumbuh di pohon Puspa, semi ternaungi, 50 mdpl, Ka.6

Distribusi: Borneo, Filipina, Papua New Guinea, India (Kerala), China (Hainan, Guangdong, Guangxi), Oceania (Samoa, Fiji) (Anoop et al. 2012).

\section{Lumut Hati Berdaun: \\ Lejeuneaceae}

*Cheilolejeunea conchifolia (A. Evans) W. Ye \& R.L. Zhu., tumbuh di atas batu, semi ternaungi, $70 \mathrm{mdpl}$, Ka.24

Distribusi: Indonesia, Filipina, USA, North Carolina.

Drepanolejeunea sp., tumbuh di akar pohon Puspa, ternaungi, 80 mdpl, Ka. 8

*Drepanolejeunea tricornua Herzog, tumbuh di akar pohon sentul, 55 mdpl, Ka.9

Distribusi: Jawa, Borneo, Seram dan New Guinea (Mizutani 1990).

*Lejeunea eckloniana Lind., tumbuh di daun paku-pakuan, ternaungi, 55 mdpl, Ka.10

Distribusi: Indonesia, Malaysia, India.

\section{Lephocoleaceae}

*Chiloscypus profundus (Nees) J.J. Engel \& R.M. Schust, tumbuh di tanah, ternaungi, 55 mdpl, Ka.12

Distribusi: Jawa, USA, Irlandia, Inggris.

\section{Plagochilaceae}

Plagochila sp., tumbuh di tanah, ternaungi, 80 mdpl, Ka.17

\section{Lumut hati:}

\section{Marchantiaceae}

Dumortiera hirsuta (Sw.) Nees., tumbuh di tanah, terbuka, 70 mdpl, Ka.13

Distribusi: Filipina, USA, Asia, China, dan Himalaya.

\section{Pallaviciniaceae}

Pallavicinia iyellii (Hook.) Caruth, tumbuh di atas batu, ternaungi, $55 \mathrm{mdpl}$, Ka.16

Distribusi: Malesia; Indonesia (Jawa) (Haerida \& Gradstein 2011 dalam Rosyanti 2017).

\section{KESIMPULAN}

Lumut yang terdapat di Kawasan Bukit Peramun Desa Air Selumar, Kecamatan Sijuk, Kabupaten Belitung sebanyak 28 jenis. Lumut sejati yang ditemukan 20 jenis terdiri dari 4 ordo dan 5 famili, sedangkan lumut hati ditemukan 8 
jenis terdiri dari 3 ordo dan 5 famili. Beberapa jenis lumut yang ditemukan di Kawasan Bukit Peramun 7 di antaranya rekaman baru untuk daerah Sumatera yaitu Fissidens virens Thwait. \& Mitt., Trichosteleum stigmosum Mitt, Brotherella nictans (Mitt.) Broth., Drepanolejeunea tricornua Herzog, Lejeunea eckloniana Lindenb, Cheilolejeunea conchifolia (A. Evans) W. Ye \& R.L. Zhu , Chiloscypus profundus (Nees) J.J. Engel \& R.M. Schust

\section{UCAPAN TERIMA KASIH}

Terima kasih penulis ucapkan kepada Jurusan Biologi Universitas Bangka Belitung, staf dan dosen Jurusan Biologi Universitas Bangka Belitung. Terimakasih kepada Bapak Adong dan Bapak Nurdin selaku ketua dan wakil Komunitas Arsel di Kawasan Bukit Peramun. Terima kasih kepada Dr.Witjaksono, M.Sc., selaku Kepala Pusat Penelitian Biologi-LIPI serta "Laboratorium Kriptogram Bidang Botani, Pusat Penelitian Biologi-LIPI, Cibinong, Bogor, Jawa Barat" yang telah memberikan izin untuk melakukan penelitian dan identifikasi herbarium lumut. Ucapan terima kasih juga disampaikan kepada semua pihak yang telah membantu hingga terpublikasinya hasil penelitian ini.

\section{DAFTAR PUSTAKA}

Alatas M, Batan N, Jia Y \& Ozdemir T. 2016. Brotherella and Encalypta species new to Turkey, Mediterranean and Southwest Asia. Plant Biosystems: 1724-5575.

Anoop KP, Manju CN, Prakashkumar R, Prajitha B \& Rajilesh VK. 2012. Trichosteleum stigmosum Mitt. (Sematophyllaceae) from Silent Valley National Park, a New Record for India. Taiwania 57(2): 222-224.

Bachri S. 2012. Keanekaragaman Lumut di Taman Nasional Gunung Merbabu Jawa Tengah [skripsi]. Bogor: Institut Petanian Bogor.

Bartram EB.1939. Mosses of the Philippines volume 68. Manila: Bureu of Printing.

Bartram EB. 1945. Mosses of Morobe District, Northeast New Guinea. J Article 48 (23): 110-126.

Bawaihaty N, Istomo \& Hilwan. 2014. Keanekaragaman dan Peran Ekologi Bryophyta di Hutan Sesaot Lombok Nusa Tenggara Barat. J Silvikultur Tropik 5(1): 13-17.

Damanhuri A \& Maideen H. 2001. Mosses of Perlis State Park at Wang Kelian, Perlis,
Peninsular Malaysia. Kangar: Jabatan Perhutanan Perlis 203-215.

Damayanti L, Iammamudin H, Jenie UA, Supriayadi H, Suryana N \& Utomo T. 2006. Koleksi Bryophyta Taman Lumut Kebun Raya Cibodas. Bogor: UPT Balai Konservasi Tumbuhan Kebun Raya Cibodas -LIPI.

Dixon H. 1932. Contributions to the moss flora of Sumatera. Ann. Bryol. 5: 17-50.

Eddy A. 1990. A Handbook of Malesian Mosses Volume 2 Leucobryaceae to Buxbaumiaceae. London: British museum (Natural History) 5-196.

Eddy A. 1988. A Handbook of Malesian Mosses Volume 1 Sphagnales to Dicranales. London: British museum (Natural History).

Eddy A. 1996. A. Handbook of Malesian Mosses Volume 3. London: HMSO Publications Centre.

Ellyzarti. 2009. Kekayaan Jenis Tumbuhan Lumut di Gunung Pesawaran di Hutan Raya Wan Abdur rahman, Propinsi Lampung. Seminar Hasil Penelitian \& Pengabdian Kepada Masyarakat, Unila. [Online].http:// lemlit.unila.ac.id/file/arsip\%202010./ Prosiding\%20Unila.(Online).http:// lemlit.unila.ac.id/file/arsip\%202010./ Prosiding\%20Dies\%20Natalis/ KELOMPOK\%20A/04\%20Ellyzarti\%20-\% 20FMIPA.pdf. (12 April 2018).

Fajriah R. 2018. Keanekaragaman Lumut (Bryophytes) Pada Berbagai Substrat di kawasan sungai Pucok Krueng Raba Kecamatan Lhoknga Kabubaten Aceh Besar sebagai Referensi praktikum Ekologi Tumbuhan [skripsi]. Fakultas Tarbiyah dan Keguruan (Ftk) Universitas Islam Negeri Ar-Raniry Darussalam-Banda Aceh.

Febrianti GN. 2015. Keanekaragaman Tumbuhan Lumut (Bryophyta) di Lingkungan Universitas Jember Serta Pemanfaatannya sebagai Buku Nonteks [skripsi]. Jember: Fakultas Keguruan dan Ilmu Pendidikan, Universitas Jember.

Gradstein SR. 2011. Guide to the Liverworts and Hornworts of Java. Bogor: Semeo Biotrop.

Gradstein SR \& Pocs T. 1989. Bryophyte. In: Tropical Rain Forest Ecosystems, H. Lieth \& MJA Werger (ed.), pp. 311-325. Amsterdam: Elsevier.

Haerida I, Graidstein SR \& Tjitosedirdjo. 2010. Lejeuneaceae subfamily Ptychanthoideae (Hepaticae) in west Java. Gardens' Bulletin 
Singapore 62 (1): 53-103.

Hardianty TD. 2018. Jenis-jenis Lumut Hati Famili Frullaniaceae Di Taman Wisata Alam Sicike-Cike Kabupaten Dairi Sumatera Utara [skripsi]. Medan: Program Studi Biologi Fakultas Matematika dan Ilmu Pengetahuan Alam Universitas Sumatera Utara.

Ho BC, Tan BC \& Hernawati NS. 2006. A checklist of mosses of Sumatera, Indonesia. $J$ Hattori Botanical laboratory 100: 143190.

Iswanto D, Santri J \& Riyanto. 2016. Keanekaragaman "komunitas bawah" Kawasan perkebunan teh, di Gunung Dempo, Kota Pagaralam, Sumatera Selatan. $J$ Pembelajaran Biologi 3(2): 104-115.

Komunitas arsel. 2018. Bukit Peramun. http:// www.belitungisland.com/new/ destination.php?id=106 [diakses 08 Februari 2018].

Mulyani E, Perwati LK \& Murningsih. 2015. Lumut Daun Epifit di Zona Tropik Kawasan Gunung Ungaran, Jawa Tengah. Junal Bioma 16 (2): 76-82.

Nadhifah A, I Noviady, Suharja, Muslim \& Suhendri Y. 2018. Keanekaragaman lumut (Musci) berukuran besar pada zona montana Kawasan Hutan Lindung Gunung Sibuatan, Sumatra Utara. Pros. Sem. Nas. Masy. Biodiv. Indon. 4 (2): 101-106.

Mizutani M .1990. Notes on the Lejeuneaceae. 16. Drepanolejeunea thwaitesiana and its related species from Asia. Journal of the Hattori Botanical Laboratory 68: 367-380.

Pradana DS. 2013. Komunitas Lumut Epifit Perkebunan Kopi di Tanjung Rusia Lampung [skripsi]. Bogor; Departemen Biologi Fakultas Matematika dan Ilmu Pengetahuan Alam Institut Pertanian Bogor.

Pradhan N \& Joshi SD. 2006. A Checklist of Fissidens species (Musci: Fissidentaceae) of Nepal. Our Nature 4: 61-68.

Putrika A. 2012. Komunitas Lumut Epifit di Kampus Universitas Depok. FPMIPA Universitas Indonesia Depok [tesis]. http:// lontar.ui.ac.id/file?file $=$ digital/20314104T30873Komunitas \%20lumu t. pdf. (6 Agustus 2018).

Rangkuti RP. 2017. Inventarisasi Jenis Lumut (Bryophyta) Di Kawasan Hutan Pelawan Namang Bangka Tengah [skripsi]. Balunijuk: Universitas Bangka Belitung.

Riani L. 2017. Inventarisasi Jenis Lumut (Bryo- phyta) di Kawasan Hutan Air Terjun Bukit Maras Desa Dalil Bangka [skripsi]. Bangka Belitung: Universitas Bangka Belitung.

Rosyanti, Afriyansyah B \& Haerida I. 2018. Keanekaragaman Lumut di Kebun Botani Bangka Flora Society Bangka. Floribunda 5 (8): 315-321.

Rosyanti. 2017. Inventarisasi Jenis Lumut (Bryophyta) Di Kebun Botani Bangka Flora Society. [skripsi]. Balunijuk: Universitas Bangka Belitung.

Rosario Del RM. 1979. Mosses Flora of The National Botanic Garden, Quezon Province Philippines. Manila: Philippine National Herbarium.

Rugayah, Retnowati A, Windadri FI \& Hidayat A. 2004. Pengumpulan Data Taksonomi. Dalam: Rugayah, Widjaja EA \& Praptiwi (eds.). Pedoman Pengumpulan Data Keanekaragaman Flora. Bogor: Puslit-LIPI.pp. 542.

Satiyem. 2012. Keanekaragaman Tumbuhan Lumut (Bryophyta) Pada Berbagai Ketinggian Hubungannya Dengan Kondisi Lingkungan di Wilayah Lereng Selatan Gunung Merapi Pasca Erupsi [skripsi]. Yogyakarta: Fakultas MIPA, Universitas Negeri Yogyakarta. hlm 7.

Schuster RM. 1980. The Hepaticae and Anthocerotae of North America volume IV. Columbia University Press: New York, 133 pp.

Siregar H. 2010. Keanekaragaman Lumut di Kawasan Hutan Lindung Aek Nauli, Sumatera Utara [skripsi]. Medan: Program Studi Bio-logi, Universitas Sumatera Utara.

Siregar ES, Ariyanti NS \& Tjitrosoedirdjo SS. 2014. Lejeuneaceae anak suku Ptychanthoideae di Hutan Sibayak Sumatra Utara. Floribunda 4(8): 218-236.

Siregar ES. 2015. The liverworts (Marchantiophyta) of Mount Sibayak North Sumatra [desertasi]. Bogor: Bogor Agricultural University.

Söderström L, Gradstein SR \& Hagborg A. 2010. Checklist of the hornworts and liverworts of Java. Phytotaxa 9: 53-149.

Tjitrosoeopomo GS. 2011. Taksonomi Tumbuhan Schizophyta, Thallophyta, Bryophyta, Pteridophyta. Yogyakarta: UGM Press.

Wati TK, Kiswardianti B \& Sulistyarsi A. 2016. Keanekaragaman Hayati. Tanaman Lumut (Bryophitha) Di Hutan Sekitar Waduk Kedung Brubus Kecamatan Pilang Keceng 
Kabupaten Madiun. J Florea 3 (1): 46-51. William DR. 2007. Calymperaceae Kindberg", Flora of North Africa. 27: 660.

Windadri FI \& Susiarti S. 2005. Leucobryum dan Potensi Pemanfaatannya; Study Kasus Masyarakat Lokal di Sekitar Cagar Alam Mandor Kalimantan Barat dan Hutan Wisata Alam Bukit Bangkirai Kalimantan Timur. Enviro 5 (1): 60-63.

Windadri FI. 2007. Lumut (Musci) di Kawasan Cagar Alam Kakenauwe dan Suaka Margasatwa Lambusango, Pulau Buton, Sulawesi Tenggara. Biodiversitas 8(3): 197203.

Windadri FI. 2009. Keragaman Lumut di Resort Karang Ranjang, Taman Nasional Ujung Kulon, Banten. J Teknik Lingkungan 10(1): 19-25.
Windadri FI. 2010. Keanekaragaman Lumut Di Taman Nasional Bukit Barisan Selatan, Provinsi Lampung, Sumatera. Berita Biologi 10(2): 159-165.

Windadri FI \& Susan D. 2013. Keanekaragaman Jenis Lumut di Kepulauan Raja Ampat Papua Barat. J Kebun Raya 16(2): 175-184.

Windadri FI. 2014. Lumut Sejati di kawasan Cagar Alam Gunung Papandayan Garut, Jawa Barat. Berita Biologi 13(13): 311-332.

Windadri FI \& Rosalina D. 2017. Rekaman Baru Tumbuhan Lumut Sejati Di Pulau Enggano. Buletin Kebun Raya 20(2): 101-110.

Yamagutchi T, Windadri FI, Haerida H, Kunimura H, Miyawaki H, Simbolon A \& Shimizu. 2005. Effect of forest fires on Bryophyta flora in East Kalimantan, Indonesia. Phyton Annales Rei Botanic 45: 561-567. 